\title{
PENGARUH KEPEMIMPINAN, PEMBAGIAN KERJA DAN KOMPENSASI TERHADAP KINERJA KARYAWAN PADA PT BANK DANAMON CABANG MANADO
}

\section{Ferdy Roring}

Fakultas Ekonomi dan Bisnis, Universitas Sam Ratulangi Manado

\section{A R T IC LE INFO}

Keywords : employees, leadership, compensation , performance.

Kata Kunci : Karyawan, Kepemimpinan,pembagian kerja dan kompensasi, kinerja

Corresponding author :

Ferdy Roring
Abstract : Research aims to understand the influence of leadership, the distribution of work and compensation towards the performance of the employees. The population research is all employees of PT Bank Danamon Branch of Manado which consisted of 254 people. Sample that is used is 72 respondents that is. With a technique used namely of multiple regression analysis with the formula is $y=b 0+$ $b 1 x 1+b 2 x 2+b 3 x 3+e$.To answer research were shown the result that: leadership, the distribution of work, and compensation together and partial have had a positive impact and significant impact on of employee performance. PT Bank Danamon Manado Branch to increase of employee performance to make the services can be effective and efficient.

Abstrak :Penelitian ini bertujuan untuk mengetahui pengaruh Kepemimpinan, Pembagian Kerja dan Kompensasi terhadap kinerja karyawan. Populasi penelitian adalah seluruh karyawan PT Bank Danamon Cabang Manado yang berjumlah 254 orang. Sampel yang digunakan adalah 72 responden yang ada. Dengan teknik yang digunakan yaitu Analisis Regresi Berganda dengan rumus adalah Y $=\mathrm{b} 0+\mathrm{b} 1 \mathrm{X} 1+\mathrm{b} 2 \mathrm{X} 2+\mathrm{b} 3 \mathrm{X} 3+\mathrm{e}$.

Untuk menjawab penelitian ini apakah menunjukkan hasil bahwa: Kepemimpinan, Pembagian Kerja, dan Kompensasi secara bersama dan parsial berpengaruh positif dan signifikan terhadap kinerja karyawan. Pada PT Bank DanamonCabang Manado agar dapat meningkatkan kinerja karyawan agar pelayanan dapat menjadi efektif dan efisien. 


\section{PENDAHULUAN}

\section{Latar Belakang Masalah}

Tenaga kerja atau karyawan merupakan sumber daya manusia yang paling berharga didalam semua organisasi. Tanpa adanya tenaga kerja atau karyawan yang berkualitas mustahil tujuan organisasi dapat tercapai dengan baik. Organisasi dilakukan dalam suatu sistem yang terdiri dari aktivitas-aktivitas yang dilakukan secara teratur dan berulang-ulang oleh sekelompok orang untuk mencapai tujuan bersama. Untuk mencapai tujuan tersebut, sebuah organisasi harus didukung oleh sumber-sumber daya yang berkualitas baik dari berwujud material, modal maupun manusia.Tidak hanya pada sektor pemerintah \& swasta, sektor publik pun juga memerlukan manajemen yang baik agar dapat memberikan pelayanan yang baik pula kepada publik atau masyarakat yang memerlukan. Maka dari itu, berhasil atau tidaknya suatu perusahaan dalam mencapai tujuannya tergantung pada keberhasilan dari para kualitas individu SDM/Perusahaan itu sendiri dalam menjalankan tugas mereka masingmasing.

Kepemimpinan merupakan gaya seorang pemimpin mempengaruhi bawahannya agar mau bekerja sama dan bekerja efektif sesuai dengan perintahnya, dengan gaya kepemimpinan yang dimiliki oleh seorang pemimpin ini yang akan digunakan untuk bisa mengarahkan sumber daya manusia dapat menggunakan semua kemampuannya dalam mencapai kinerja yang baik.Dalam meningkatkan kinerja karyawan perlu adanya peningkatan sumber daya manusia salah satunya adalah membedakan pekerjaan dengan menggunakan prinsip pembagian kerja. Oleh karena itu, setiap organisasi atau perusahaan perlu menempatkan orang yang tepat untuk pekerjaan yang sesuai, sehingga dengan adanya pembagian kerja dimaksudkan untuk menghasilkan produksi atau hasil kerja yang baik serta memudahkan karyawan dalam menjalankan tugas yang dikerjakannya. Pembagian kerja didasarkan pada pendidikan (keahlian), usia, dan jenis kelamin.

Selain faktor kepemimpinan dan pembagian kerja, perusahaan juga harus memperhatikan pemberian kompensasi bagi para karyawannya. Kompensasi merupakan faktor yang juga penting bagi karyawan sebagai individu karena besarnya kompensasi mencerminkan ukuran nilai karya mereka di antara para karyawan itu sendiri, keluarga, dan masyarakat. Kompensasi adalah penghasilan yang diberikan oleh Perseroan kepada Pegawai dalam bentuk uang untuk kurun waktu bulanan atau tahunan. Kompensasi juga merupakan imbalan atau balas jasa yang diberikan perusahaan kepada tenaga kerja sebagai akibat dari prestasi yang telah diberikannya dalam rangka mencapai tujuan perusahaan. Pemberian kompensasi kepada karyawan seharusnya mendapat perhatian yang utama dari pimpinan, karena dengan gaji atau upah yang cukup dan memadai akan membawapengaruh positif terhadap semangat kerja dan kinerja karyawan dibanding dengan sumbangan tenaga maupun keahlian yang diberikan oleh perusahaan. Dengan demikian, diharapkan tujuan perusahaan tersebut bisa tercapai dengan baik.

Untuk mencapai kinerja karyawan yang efektif di PT Bank Danamon Cabang Manado hal tersebut tentu dipengaruhi oleh kepemimpinan yang diterapkan pada perusahaan. Pada Prinsipnya Kepemimpinan memotivasi bawahan untuk berbuat lebih baik dari apa yang bisa dilakukan, dengan kata lain dapat meningkatkan kepercayaan atau keyakinan diri bawahan yang nantinya akan berpengaruh terhadap peningkatan kinerja. Di sisi lain tuntutan perusahaan terhadap pegawai untuk meningkatkan kinerja harus diimbangi dengan pembagian kerja yang baik dan terstruktur sehingga karyawan mampu dan bisa menjalankan pekerjaan yang dibebankan dengan efektif. Selain itu, pemberian kompensasi yang sesuai, adil dan layak diharapkan dapat meningkatkan kinerja dari masing-masing karyawan.

Adapun PT Bank Danamon Cabang Manado memiliki unit cabang yaitu Cabang Manado Sutomo, Cabang Manado Toar, Cabang Manado Bahu dan Cabang Manado Ranotana. Beberapa aspek yang menyebabkan kinerja PT Bank Danamon belum optimal, yaitu dilihat dari pembagian kerja marketing funding dan landing masih tumpang tindih dalam pengelolah nasabah. 


\section{Tujuan Penelitian}

Adapun tujuan yang ingin dicapai dalam penelitian ini adalah:

1. Untuk mengetahui pengaruh Kepemimpinan terhadap Kinerja Karyawan di PT Bank Danamon Cabang Manado.

2. Untuk mengetahui pengaruh Kompensasi terhadap Kinerja karyawan di PT Bank Danamon Cabang Manado

3. Untuk mengetahui pengaruh Kepemimpinan, Pembagian Kerja dan Kompensasi terhadap Kinerja karyawan di PT Bank Danamon Cabang Manado

\section{Kepemimpinan}

\section{TINJAUAN PUSTAKA}

Kepemimpinan dalam pengertian umum berarti menunjukkan suatu proses kegiatan seseorang dalam hal memimpin, membimbing, mempengaruhi atau mengontrol pikiran, perasaan dan tingkah laku terhadap orang lain yang berada di bawah pengawasannya.

Kepemimpinan menurut Terry (dalam Thoha, 2004) adalah aktivitas untuk mempengaruhi orang-orang supaya diarahkan mencapai tujuan organisasi. Pemimpin transformasional memiliki karakteristik: kharisma (memberikan visi dan misi, menanamkan kebanggaan, memperoleh respek dan kepercayaan), inspirasi (mengkomunikasikan harapan yang tinggi, menggunakan lambang-lambang untuk memfokuskan upaya, mengungkapkan maksud-maksud penting dalam cara yang sederhana, rangsangan intelektual (menggalakkan kecerdasan, rasionalitas dan pemecahan masalah yang teliti), dan pertimbangan yang diindividualkan (memberikan perhatian pribadi, memperlakukan tiap karyawan secara individual, melatih dan menasehati bawahannya).

Menurut Hasibuan kepemimpinan (leadership) yang ditetapkan oleh seorang manajer dalam organisasi dapat menciptakan integrasi yang serasi dan mendorong gariah kerja karyawan untuk mencapai sasaran yang maksimal. Menurutnya kepemimpinan adalah cara seorang pemimpin mempengaruhi perilaku bawahan agar mau bekerja sama dan bekerja secara produktif untuk mencapai tujuan organisasi.

\section{Indikator Kepemimpinan}

Variabel Kepemimpinan dapat diukur dengan indikator yaitu :

- Pemimpin menjadi teladan

- Pembagian tugas dan pekerjaan dengan baik dan jelas

- Pengambilan keputusan dan bijaksana

- Bimbingan terhadap bawahan

- Memberikan umpan balik

\section{Pembagian Kerja}

Menurut Hasibuan (2007). Pembagian kerja yaitu informasi tertulis yang menguraikan tugas dan tanggung jawab, kondisi pekerjaan, hubungan pekerjaan, dan aspek-aspek pekerjaan pada suatu jabatan tertentu dalam organisasi.

\section{Manfaat Pembagian Kerja}

Manfaat pembagian kerja yaitu agar suatu pekerjaan dapat terselenggara dengan baik sesuai rencana dan dapat diketahui dengan jelas tujuan organisasi, dan pegawai yanga bertanggung jawab atas terselenggaranya pekerjaan tersebut. Menurut A.S Moenir (2002:26-27) manfaat pembagian kerja adalah:

1. Memudahkan seseorang melakukan pekerjaanya atau tugasnya tanpa menunggu perintah atau komando

2. Diketahui dengan jelas batas wewenang dan tangggung jawab dari pekerjaan itu

3. Tidak meragukan dalam pemberian tugas atau pelaksanaan tugas

4. Memudahkan pengawasan

5. Tidak terjadinya simpang siur atau benturan dalam pelaksanaan pekerjaan

6. Menjadi dasar pertimbangan dalam penentaun kebutuhan pendidikan 


\section{Indikator Pembagian Kerja}

Untuk mengukur indikator pembagian kerja, berikut adalah hal-hal yang penting :

1. Kemampuan karyawan menyelesaikan tugas

2. Kesesuaian pekerjaan dengan kemampuan karyawan

3. Volume pekerjaan

4. Kesesuaian pekerjaan dengan latar belakang pendidikan

5. Tingkat kenyamanan karyawan dengan pekerjaan

\section{Kompensasi}

Kompensasi adalah semua pendapatan yang berbentuk uang, barang langsung atau tidak langsung yang diterima karyawan sebagai imbalan atas jasa yang diberikan kepada perusahaan (Malayu S.P. Hasibuan, 2007:54). Kompensasi berbentuk uang, artinya gaji dibayar dengan sejumlah uang kartal kepada karyawan yang bersangkutan. Kompensasi berbentuk barang, artinya gaji dibayar dengan barang.

\section{Terminologi Kompensasi}

Beberapa terminologi dalam kompensasi :

1. Upah/gaji. Upah (wages) biasanya berhubungan dengan tarif gaji perjam (semakin lama kerjanya, semakin besar bayarannya). Upah merupakan basis bayaran yang kerap digunakan bagi pekerja-pekerja produksi dan pemeliharaan. Sedangkan gaji (salary) umumnya berlaku untuk tarif mingguan, bulanan atau tahunan.

2. Insentif, (incentive) merupakan tambahan-tambahan gaji diatas atau diluar gaji atau upah yang diberikan oleh organisasi. Program-program insentif disesuaikan dengan memberikan bayaran tambahan berdasarkan produktivitas, penjualan, keuntungan-keuntungan atau upaya-upaya pemangkasan biaya.

3. Tunjangan (Benefit). Contoh-contoh tunjangan seperti asuransi kesehatan, asuransi jiwa, liburan-liburan yang ditanggung perusahaan, program pensiun dan tunjangan-tunjangan lainnya yang berhubungan dengan kepegawaian.

4. Fasilitas (Facility) adalah kenikmatan/fasilitas seperti mobil perusahaan, keanggotaan klub, tempat parkir khusus.

\section{Jenis-jenis Kompensasi}

Komponen-komponen dari keseluruhan program gaji secara umum dikelompokkan kedalam kompensasi finansial langsung, tak langsung dan non finansial. Kompensasi finansial secara langsung berupa; bayaran pokok (gaji dan upah), bayaran prestasi, bayaran insentif (bonus, komisi, pembagian laba/keuntungan dan opsi saham) dan bayaran tertangguh (program tabungan dan anuitas pembelian saham). Kompensasi finansial tidak langsung berupa; program-program proteksi (asuransi kesehatan, asuransi jiwa, pensiun, asuransi tenaga kerja), bayaran diluar jam kerja (liburan, hari besar, cuti tahunan dan cuti hamil) dan fasilitas-fasilitas seperti kendaran,ruang kantor dan tempat parkir. Kompensasi non finansial, berupa pekerjaan (tugas-tugas yang menarik, tantangan, tanggung jawab, pengakuan dan rasa pencapaian). Lingkungan kerja (kebijakan-kebijakan yang sehat, supervise yang kompoten, kerabat yang menyenangkan, lingkungan kerja yang nyaman).

\section{Kinerja}

Kinerja adalah suatu hasil yang dicapai seseorang dalam melaksakan tugas-tugasnya yang dibebankan kepadanya yang didasarkan atas kecakapan, pengalaman, dan kesungguhan serta waktu (Hasibuan 2011 : 94).

Menurut Umam (2010:189) kinerja adalah hasil kerja yang dicapai oleh individu sesuai dengan peran atau tugasnya dalam periode tertentu, yang dihubungkan dengan ukuran nilai atau standar tertentu dari organisasi tempat individu tersebut bekerja. 


\section{Indikator Kinerja}

Prestasi atau kinerja adalah catatan tentang hasil yang diperoleh dari fungsi-fungsi pekerjaan tertentu atau kegiatan selama kurun waktu tertentu.Menurut Mangkunegara (2002:67) hal yang perlu diperhatikan oleh manajer sumber daya manusia dalam kinerja karyawan dengan indikator :

1. Kualitas kerja adalah menunjukan hasil kerja yang dicapai dari segi ketepatan, ketelitian dan keterampilan.

2. Kuantitas kerja adalah menunjukkan hasil kerja yang dicapai dari segi keluaran atau hasil tugas-tugas rutinitas dan kecepatan dalam menyelesaikan tugas itu sendiri.

3. Kerjasama menyatakan kemampuan karyawan dalam berpartisipasi dan bekerjasama dengan orang lain dalam menyelesaikan tugas.

4. Tanggung jawab menyatakan seberapa besar karyawan dalam menerima dan melaksanakan pekerjaannya.

5. Inisiatif yakni bersemangat dalam menyelesaikan tugasnya, serta kemampuan dalam membuat suatu keputusan yang baik tanpa adanya pengarahan terlebih dahulu.

\section{Kerangka Konseptual}

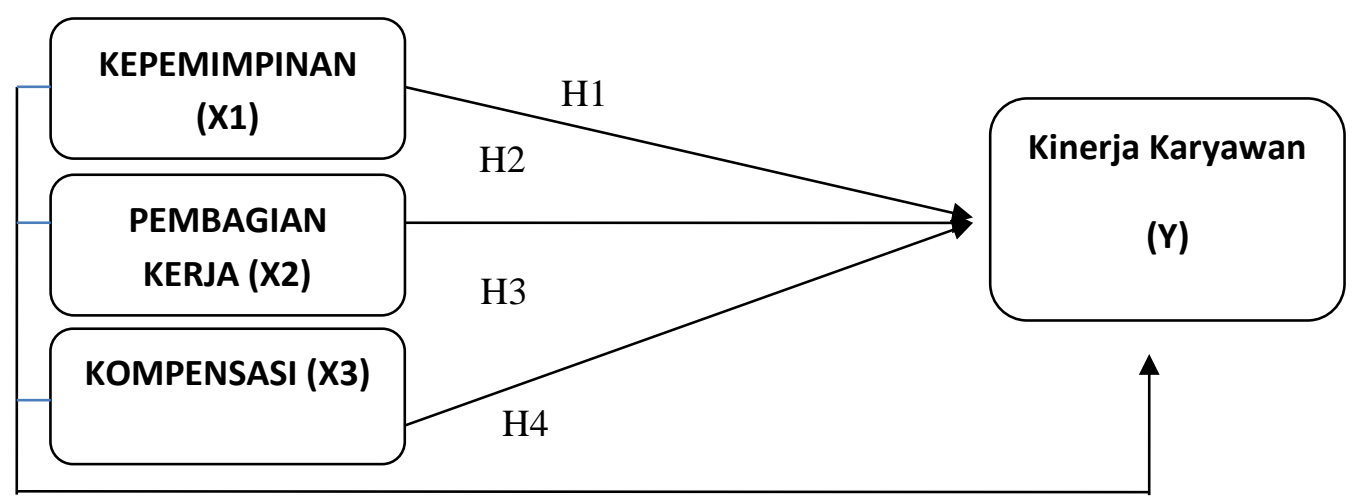

Gambar 1 Kerangka Berpikir Penelitian

\section{Jenis Penelitian}

\section{METODOLOGI PENELITIAN}

Berdasarkan metode yang digunakan maka penelitian ini merupakan penelitian kuantitatif. Berdasarkan tingkat explansi penelitian ini merupakan penelitian asosiatif, menurut Sugiyono (2012: 55) asosiatif adalah suatu pertanyaan penelitian yang bersifat menanyakan hubungan antara dua variabel atau lebih.

\section{Tempat dan Waktu Penelitian}

Tempat penelitian di PT. Bank Danamon cabang Manado yang berlokasi Dijalan Dr Sutomo Manado Waktu penelitian diperkirakan 6 bulan.

\section{Populasi dan Sampel}

Populasi dalam penelitian ini adalah karyawan di kantor PT. Bank Danamon cabang Manado pada tahun 2016 yaitu sebesar 254 karyawan. Yang menjadi sampel dalam penelitian ini adalah karyawan di kantor PT. Bank Danamon cabang Manado.

\section{Analisis Regresi Linear Berganda}


Analisis yang digunakan dalam penelitian ini adalah analisis regresi berganda. Analisis regresi linear berganda adalah suatu metode statistik umum yang digunakan untuk meneliti hubungan antara sebuah variabel dependen dengan beberapa variabel independen.

$$
\begin{array}{cl}
\mathbf{Y}=\mathbf{b}_{\mathbf{0}}+\mathbf{b}_{\mathbf{1}} \mathbf{X}_{\mathbf{1}+} & \mathbf{b}_{\mathbf{2}} \mathbf{X}_{\mathbf{2}+\mathbf{b}_{\mathbf{3}} \mathbf{X}_{\mathbf{3}+\mathbf{e}}} \\
\text { Dimana } & : \\
\mathrm{X}_{1} & =\text { Kepemimpinan } \\
\mathbf{X}_{2} & =\text { Pembagian Kerja } \\
\mathrm{X}_{3} & =\text { Kompensasi } \\
\mathrm{Y} & =\text { Kinerja Karyawan } \\
\mathrm{b}_{0} & =\text { Intersep } \\
\mathrm{e} & =\text { Faktor pengganggu }
\end{array}
$$

\section{Deskripsi Responden}

\section{HASIL PENELITIAN DAN PEMBAHASAN}

Dalam Penelitiani ini deskripsi responden yang berjumlah 72 orang responden. Tabel 5.1 menjelaskan latar belakang responden yang bekerja di PT Bank Danamon Manado.

Tabel. 1 Latar Belakang Responden Penelitian

\begin{tabular}{lcccc}
\hline No & Karakteristik & Golongan & Jumlah & $\begin{array}{c}\text { Persen } \\
(\mathbf{\%})\end{array}$ \\
\hline $1 . \quad$ Jenis Kelamin & Pria & 49 & 68,1 \\
& & Wanita & 23 & 31,9 \\
& & $\mathbf{7 2}$ & $\mathbf{1 0 0}$ \\
\hline $2 . \quad$ Usia (tahun) & $21-30$ & 23 & 31,9 \\
& & $31-40$ & 43 & 59,7 \\
& & $41-50$ & 4 & 5,6 \\
& & & 2 & 2,8 \\
\hline \multirow{3}{*}{ Jabatan } & & $\mathbf{7 2}$ & $\mathbf{1 0 0}$ \\
& & Manager/Pinca & 5 & 6,9 \\
& & Teller/CS & 18 & 25 \\
& & Security/Cleaning Service & 22 & 30,6 \\
& Staff Marketing & 27 & 37,5 \\
\hline \multirow{3}{*}{ 4. } & & $\mathbf{7 2}$ & $\mathbf{1 0 0}$ \\
& & SMA/SMK & 29 & 40,3 \\
& & Diploma & 19 & 26,4 \\
& & Sarjana/Magister & 24 & 33,3 \\
& & & $\mathbf{7 2}$ & $\mathbf{1 0 0}$ \\
\hline
\end{tabular}

Sumber: Data Olahan (2017)

Tabel. 1 latar belakang responden yang berjumlah 72 orang responden, mayoritas responden pria $(68,1 \%)$, berusia muda antara 31-40 tahun (59,7\%), jabatan sebagai staff $(37,5 \%)$, serta pendidikan terakhir adalah SMA/SMK $(40,3 \%)$. 


\section{Persamaan Regresi Ganda}

Regresi berganda dapat dilihat sebagai berikut:

Tabel. 2 Regresi Berganda

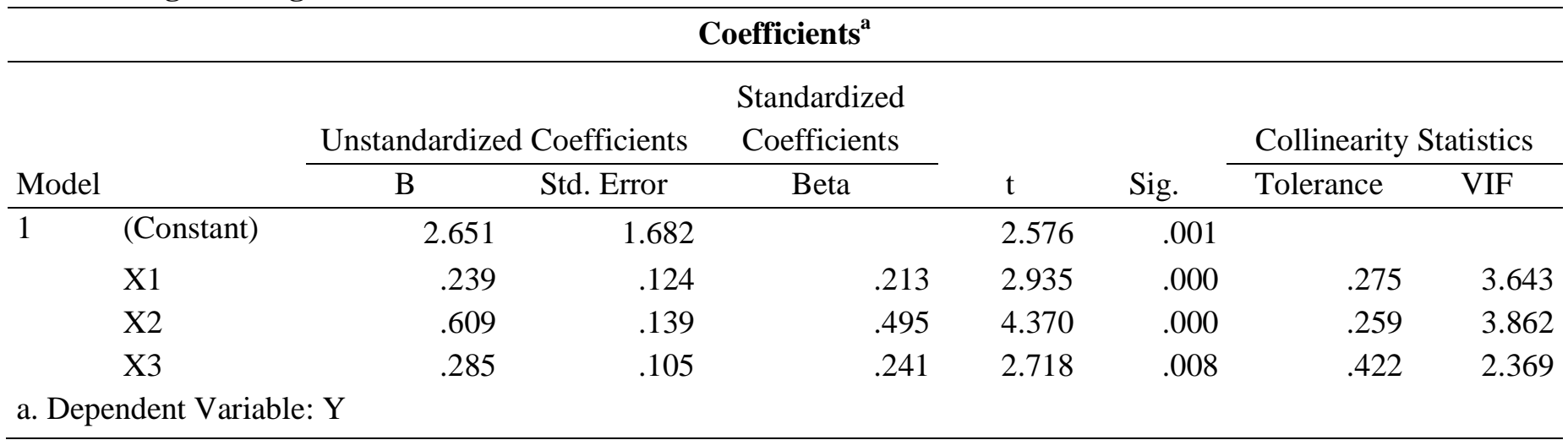

Sumber: Data Olahan (2017)

Berdasarkan Tabel 2, dengan melihat koefisien beta $(\beta)$ untuk masing-masing variabel maka persamaan regresi ganda yang dihasilkan adalah sebagai berikut :

$Y=2,651+0,239 X_{1}+0,609 X_{2}+0,285 X_{3}$

Dari persamaan regresi berganda di atas, dapat menginformasikan bahwa: $a=2,651$ adalah bilangan konstanta yang berarti apabila variabel bebas yaitu $\mathrm{X}_{1}, \mathrm{X}_{2}$ dan $\mathrm{X}_{3}$ sama dengan nol, maka kinerja karyawan adalah 2,651 .

Koefisien $b_{1}=0,239$ adalah besarnya koefisien regresi $X_{1}$, yang berarti bahwa setiap peningkatan satu satuan skor variabel $\mathrm{X}_{1}$ akan meningkatkan kinerja karyawan sebesar 0,239 dengan asumsi variabel lainnya yang diteliti adalah konstan.

Koefisien $b_{2}=0,609$ adalah besarnya koefisien regresi X2 yang berarti setiap peningkatan satu satuan skor X2 akan meningkatkan kinerja karyawan sebesar 0,609 dengan asumsi variabel lain dalam penelitian ini adalah konstan.

Koefisien $b_{3}=0,285$ adalah besarnya koefisien regresi X3 yang berarti setiap peningkatan satu satuan skor X3 akan meningkatkan kinerja karyawan sebesar 0,285 dengan asumsi variabel lain dalam penelitian ini adalah konstan.

\section{Uji Hipotesis Secara Parsial (Uji t)}

Untuk melihat besarnya pengaruh secara parsial antara kepemimpinan (X1), pembagian kerja (X2) dan Kompensasi (X3) terhadap kinerja karyawan (Y) digunakan kriteria sebagai berikut :

1. Jika signifikansi (sig.) t untuk variabel kepemimpinan $>0,05$, maka hipotesis nul $\left(\mathrm{H}_{\mathrm{o}}\right)$ yang menyatakan bahwa kepemimpinan (X1) tidak berpengaruh terhadap kinerja karyawan adalah diterima; sekaligus menolak hipotesis alternatif $\left(\mathrm{H}_{\mathrm{a}}\right)$ yang menyatakan bahwa kepemimpinan $(\mathrm{X} 1)$ berpengaruh terhadap kinerja karyawan.

Jika signifikansi (sig.) t untuk variabel kepemimpinan $<0,05$, maka hipotesis nul $\left(\mathrm{H}_{\mathrm{o}}\right)$ yang menyatakan bahwa kepemimpinan (X1) tidak berpengaruh terhadap kinerja karyawan adalah ditolak; sekaligus menerima hipotesis alternatif $\left(\mathrm{H}_{\mathrm{a}}\right)$ yang menyatakan bahwa kepemimpinan (X1) berpengaruh terhadap kinerja karyawan.

Berdasarkan hasil perhitungan yang dapat dilihat pada tabel 5.6 diperoleh nilai signifikansi (sig.) t untuk kepemimpinan adalah sebesar 0,000 lebih kecil dari 0,05. Dengan demikian maka hipotesis nul $\left(\mathrm{H}_{\mathrm{o}}\right)$ ditolak; 
sekaligus menerima hipotesis alternatif $\left(\mathrm{H}_{\mathrm{a}}\right)$ yang menyatakan bahwa kepemimpinan (X1) berpengaruh terhadap kinerja karyawan.

Uji t dengan kriteria uji hipotesis dengan membandingkan t hitung dengan $\mathrm{t}$ tabel, yaitu

- $\mathrm{t}_{\text {hitung }} \leq \mathrm{t}_{\text {tabel }}(\alpha=0,05)$, maka $\mathrm{H}_{\mathrm{o}}$ diterima sehingga $\mathrm{H}_{\mathrm{a}}$ ditolak.

- $t_{\text {hitung }}>t_{\text {tabel }}(\alpha=0,05)$, maka $H_{o}$ ditolak sehingga $H_{a}$ diterima.

Berdasarkan hasil perhitungan untuk variabel kepemimpinan, $\mathrm{t}$ hitung 2,935 $>\mathrm{t}$ tabel $(\mathrm{df}=68 ; \alpha=5 \%)$ 1,668.

Dengan demikian Ho ditolak, dan menerima Ha yang menyatakan ada pengaruh Kepemimpinan terhadap Kinerja Karyawan.

2. Jika signifikansi (sig.) t untuk variabel pembagian kerja $>0,05$, maka hipotesis nul $\left(\mathrm{H}_{\mathrm{o}}\right)$ yang menyatakan bahwa pembagian kerja (X2) tidak berpengaruh terhadap kinerja karyawan adalah diterima; sekaligus menolak hipotesis alternatif $\left(\mathrm{H}_{\mathrm{a}}\right)$ yang menyatakan bahwa pembagian kerja (X2) berpengaruh terhadap kinerja karyawan.

Jika signifikansi (sig.) t untuk variabel pembagian kerja $<0,05$, maka hipotesis nul $\left(\mathrm{H}_{\mathrm{o}}\right)$ yang menyatakan bahwa pembagian kerja (X2) tidak berpengaruh terhadap kinerja karyawan adalah ditolak; sekaligus menerima hipotesis alternatif $\left(\mathrm{H}_{\mathrm{a}}\right)$ yang menyatakan bahwa pembagian kerja (X2) berpengaruh terhadap kinerja karyawan.

Berdasarkan hasil perhitungan yang dapat dilihat pada tabel 4.6 diperoleh nilai signifikansi (sig.) t untuk pembagian kerja adalah sebesar 0,000 lebih kecil dari 0,05. Dengan demikian maka hipotesis nul $\left(\mathrm{H}_{\mathrm{o}}\right)$ ditolak; sekaligus menerima hipotesis alternatif $\left(\mathrm{H}_{\mathrm{a}}\right)$ yang menyatakan bahwa pembagian kerja $(\mathrm{X} 2)$ berpengaruh terhadap kinerja karyawan.

Uji t dengan kriteria uji hipotesis dengan membandingkan t hitung dengan $\mathrm{t}$ tabel, yaitu

- $\quad t_{\text {hitung }} \leq t_{\text {tabel }}(\alpha=0,05)$, maka $H_{o}$ diterima sehingga $H_{a}$ ditolak.

- $\quad t_{\text {hitung }}>t_{\text {tabel }}(\alpha=0,05)$, maka $\mathrm{H}_{0}$ ditolak sehingga $\mathrm{H}_{\mathrm{a}}$ diterima.

Berdasarkan hasil perhitungan untuk variabel pembagian kerja, $t$ hitung 4,370 $>\mathrm{t}$ tabel $(\mathrm{df}=68 ; \alpha=5 \%)$ 1,668. Dengan demikian Ho ditolak, dan menerima Ha yang menyatakan ada pengaruh Pembagian Kerja terhadap Kinerja Karyawan.

3. Jika signifikansi (sig.) t untuk variabel Kompensasi> 0,05, maka hipotesis nul $\left(\mathrm{H}_{\mathrm{o}}\right)$ yang menyatakan bahwa Kompensasi (X3) tidak berpengaruh terhadap kinerja karyawan adalah diterima; sekaligus menolak hipotesis alternatif $\left(\mathrm{H}_{\mathrm{a}}\right)$ yang menyatakan bahwa Kompensasi (X3) berpengaruh terhadap kinerja karyawan.

Jika signifikansi (sig.) t untuk variabel Kompensasi< 0,05, maka hipotesis nul $\left(\mathrm{H}_{\mathrm{o}}\right)$ yang menyatakan bahwa Kompensasi (X3) tidak berpengaruh terhadap kinerja karyawan adalah ditolak; sekaligus menerima hipotesis alternatif $\left(\mathrm{H}_{\mathrm{a}}\right)$ yang menyatakan bahwa Kompensasi (X3) berpengaruh terhadap kinerja karyawan.

Berdasarkan hasil perhitungan yang dapat dilihat pada tabel 4.6 diperoleh nilai signifikansi (sig.) t untuk Kompensasi adalah sebesar 0,000 lebih kecil dari 0,05. Dengan demikian maka hipotesis nul $\left(\mathrm{H}_{\mathrm{o}}\right)$ ditolak; sekaligus menerima hipotesis alternatif $\left(\mathrm{H}_{\mathrm{a}}\right)$ yang menyatakan bahwa Kompensasi (X3) berpengaruh terhadap kinerja karyawan.

Uji t dengan kriteria uji hipotesis dengan membandingkan $\mathrm{t}$ hitung dengan $\mathrm{t}$ tabel, yaitu

- $\quad t_{\text {hitung }} \leq \mathrm{t}_{\text {tabel }}(\alpha=0,05)$, maka $\mathrm{H}_{\mathrm{o}}$ diterima sehingga $\mathrm{H}_{\mathrm{a}}$ ditolak.

- $\quad t_{\text {hitung }}>t_{\text {tabel }}(\alpha=0,05)$, maka $H_{o}$ ditolak sehingga $H_{a}$ diterima.

Berdasarkan hasil perhitungan untuk variabel Kompensasi, $t$ hitung $2,718>\mathrm{t}$ tabel $(\mathrm{df}=68 ; \alpha=5 \%) 1,668$. Dengan demikian Ho ditolak, dan menerima Ha yang menyatakan ada pengaruh Kompensasi terhadap Kinerja Karyawan. 


\section{Uji Hipotesis Secara Simultan (Uji F)}

Pengujian dilakukan dengan cara membandingkan angka taraf signifikan hasil perhitungan dengan taraf signifikan $0,05(5 \%)$ dengan kriteria sebagai berikut:

Jika signifikansi $\mathrm{F}>0,05$, maka hipotesis nul $\left(\mathrm{H}_{\mathrm{o}}\right)$ yang menyatakan bahwa kepemimpinan, pembagian kerja, dan Kompensasitidak berpengaruh terhadap kinerja karyawan adalah diterima; sekaligus menolak hipotesis alternatif $\left(\mathrm{H}_{\mathrm{a}}\right)$ yang menyatakan bahwa kepemimpinan, pembagian kerja, dan Kompensasiberpengaruh terhadap kinerja karyawan.

Jika signifikansi $\mathrm{F}<0,05$, maka hipotesis nul $\left(\mathrm{H}_{\mathrm{o}}\right)$ yang menyatakan bahwa kepemimpinan, pembagian kerja, dan Kompensasi tidak berpengaruh terhadap kinerja karyawan adalah ditolak; sekaligus menerima hipotesis alternatif $\left(\mathrm{H}_{\mathrm{a}}\right)$ yang menyatakan bahwa kepemimpinan, pembagian kerja, dan Kompensasi berpengaruh terhadap kinerja karyawan.

Tabel 3. merupakan Tabel Anova untuk uji F dan signifikan F.

Tabel 3 Anova

\begin{tabular}{lrrrrrr}
\hline \multicolumn{7}{c}{ ANOVA $^{\mathrm{a}}$} \\
\hline Model & & Sum of Squares & Df & Mean Square & \multicolumn{1}{c}{ F } & \multicolumn{1}{c}{ Sig. } \\
\hline 1 & Regression & 577.635 & 3 & 192.545 & 77.772 & $.000^{\mathrm{b}}$ \\
& Residual & 168.351 & 68 & 2.476 & & \\
& Total & 745.986 & 71 & & &
\end{tabular}

a. Dependent Variable: Y

b. Predictors: (Constant), X3, X1, X2

Sumber: Olahan (2017)

Berdasarkan Tabel 3, dapat dilihat bahwa angka F sebesar 77,772 dengan tingkat signifikan sebesar 0,000 $<0.05$. Dengan demikian maka hipotesis nul $\left(\mathrm{H}_{\mathrm{o}}\right)$ yang menyatakan bahwa kepemimpinan, pembagian kerja, dan Kompensasi tidak berpengaruh terhadap kinerja karyawan adalah ditolak; sekaligus menerima hipotesis alternatif $\left(\mathrm{H}_{\mathrm{a}}\right)$ yang menyatakan bahwa kepemimpinan, pembagian kerja, dan Kompensasi berpengaruh terhadap kinerja karyawan.

\section{Pembahasan}

Pengaruh Kepemimpinan, Pembagian Kerja, Dan Kompensasi Terhadap Kinerja karyawan.

Berdasarkan Uji Statistik dapat dijelaskan bahwa Kepemimpinan, Pembagian Kerja dan Kompensasi berpengaruh secara bersama-sama terhadap kinerja karyawan di PT Bank Danamon Cabang Manado dengan nilai koefisien yang signifikan. Berdasarkan hasil uji statistik dapat dijelaskan bahwa kinerja karyawan dipengaruhi oleh: Kepemimpinan, Pembagian Kerja dan Kompensasi.

Hasil ini mengindikasikan bahwa model ini dipakai dalam memprediksi Kinerja karyawan khususnya Kinerja Karyawan di PT Bank Danomon cabang Manado.

\section{Pengaruh Kepemimpinan Terhadap Kinerja Karyawan}

Berdasarkan Uji Statistik dapat dijelaskan bahwa Kepemimpinan berpengaruh terhadap Kinerja karyawan di PT Bank Danamon cabang Manado dengan nilai koefisien yang signifikan. Berdasarkan hasil uji statistik dapat dijelaskan bahwa Kepemimpinan seperti: teladan, pembagian tugas, pengambilan keputusan, bimbingan, umpan balik berpengaruh terhadap Kinerja karyawan di PT Bank Danamon cabang Manado. 
Selain itu juga Kepemimpinan merupakan salah satu variabel yang kuat atau variable dominan pengaruhnya terhadap loyalitas Kinerja karyawan dalam penelitian. Hal ini menjadikan Kepemimpinan sebagai variabel terutama yang dapat dijadikan acuan perusahaan untuk mengukur dan menganalisa kinerja karyawan.

Hasil ini sesuai dan memperkuat penelitian sebelumnya khususnya penelitian-penelitian dari; Sofyan Sauri Rakhman (2010). Dalam Penelitiannya tersebut sama-sama menemukan bahwa Kepemimpinan terbukti memiliki pengaruh terhadap Kinerja karyawan. Hal ini mengindikasikan bahwa Kepemimpinan merupakan salah satu variabel penting atau prediktor dari Kinerja karyawan khususnya Kinerja karyawan di PT bank Danamon Cabang Manado.

\section{Pengaruh Pembagian Kerja terhadap Kinerja Karyawan}

Berdasarkan Uji Statistik dapat dijelaskan bahwa Pembagian kerja berpengaruh terhadap Kinerja karyawan PT Bank Danamon Cabang Manado dengan nilai koefisien yang signifikan. Berdasarkan hasil uji statistik dapat dijelaskan bahwa Pembagian kerja seperti: kemampuan, kesesuaian pekerjaan, volume pekerjaan, tingkat kenyamanan berpengaruh terhadap Kinerja karyawan di PT Bank Danamon Cabang Manado.

Hasil ini sesuai dan memperkuat penelitian sebelumnya khususnya penelitian-penelitian dari Eka Idham Iip K Lewa dan Subowo (2005); Vera Parlinda dan M. Wahyuddin (2004); Sofyan Sauri Rakhman (2010). Ketiga penelitian tersebut sama-sama menemukan bahwa Pembagian kerja terbukti memiliki pengaruh terhadap kinerja karyawan.

Hal ini mengindikasikan bahwa Pembagian kerja merupakan salah satu variabel penting atau prediktor dari Kinerja karyawan khususnya Kinerja karyawan di PT Bank Danamon Cabang Manado.

\section{Pengaruh Kompensasi terhadap Kinerja Karyawan}

Berdasarkan Uji Statistik dapat dijelaskan bahwa Kompensasi berpengaruh terhadap Kinerja Karyawan PT Bank Danamon Cabang Manado dengan nilai koefisien yang signifikan. Berdasarkan hasil uji statistik dapat dijelaskan bahwa Kompensasi seperti: adil, layak, gaji, upah, insentif, fasilitas, serta tunjangan berpengaruh terhadap Kinerja karyawan PT Bank Danamon Cabang Manado

Hasil ini sesuai dan memperkuat penelitian sebelumnya khususnya penelitian Sofyan Sauri Rakhman (2010). Mengatakan sebagai berikut penelitian tersebut menemukan bahwa Kompensasi terbukti memiliki pengaruh terhadap Kinerja karyawan.

Hal ini mengindikasikan bahwa Kompensasi merupakan salah satu variabel penting atau prediktor dari Kinerja karyawan khususnya Kinerja karyawan di PT Bank Danamon Cabang Manado.

\section{PENUTUP}

\section{Kesimpulan}

Kesimpulan dari penelitian ini yaitu:

1. Berdasarkan hasil uji hipotesis khususnya model penelitian yang terdiri dari Kepemimpinan, Pembagian kerja dan Kompensasi memilikipengaruh yang positif dan signifikan terhadap Kinerja karyawan. Model ini berlaku pada Kinerja karyawan PT Bank Danamon Cabang Manado

2. Berdasarkan hasil uji hipotesis ditemukan bahwa Kepemimpinan memiliki pengaruh yang signifikan dan positif terhadap terhadap Kinerja karyawan di PT Bank Danamon Cabang Manado. Kepemimpinan juga merupakan variabel paling dominan atau yang paling kuat berpengaruh terhadap Kinerja Karyawan dibandingkan dengan variabel lainnya dalam model penelitian ini.

3. Berdasarkan hasil uji hipotesis ditemukan bahwa Pembagian kerja memiliki pengaruh yang signifikan dan positif terhadap Kinerja karyawan PT Bank Danamon Cabang Manado. 
4. Berdasarkan hasil uji hipotesis ditemukan bahwa Kompensasi memiliki pengaruh yang signifikan dan positif terhadap Kinerja karyawan PT Bank Danamon Cabang Manado.

\section{Saran}

Berdasarkan hasil pembahasan dalam penelitian ini, adapun saran yaitu:

1. Pihak perusahaan dan manajemen PT Bank Danamon Cabang Manado sebagai satu-satunya penyedia layanan dan suplai air di Manado sebaiknya lebih memperhatikan bagaimana sistem kepemimpinan, Pembagian kerja dan Kompensasi yang diterapkan di perusahaan. Karena dari hasil penelitian ini ketiga variabel tersebut sangat berpengaruh terhadap kinerja karyawan.

2. Peneliti lainnya yang berfokus pada penelitian bidang ilmu manajemen khusunya sumber daya manusia perlu memperhatikan hasil temuan ini dengan mereplikasi hasil penelitian ini pada objek penelitian lainnya di perusahaan atau industri lain di Indonesia.

\section{DAFTAR PUSTAKA}

Abdul Azis Wahab (2008), “Kepemimpinan terhadap organisasi”. Bandung Alfabeta.

A. Anwar Prabu Mangkunegara, MSi. 2008. Evaluasi Kinerja Sumber Daya

Manusia.Bandung: Refika Aditama.

Handoko, T. Hani. 2012.Manajemen Personalia dan Sumber Daya Manusia.Yogyakarta:BPFE

Hariandja, Marihot Tua Efendi. (2007).Manajemen Sumber Daya Manusia Pengadaan, Pengembangan, Pengkompensasian, dan Peningkatan Produktivitas Pegawai. Jakarta : Grasindo

Hasibuan, Malayu S.P., 2011. Manajemen Sumber Daya Manusia. Bumi Aksara, Jakarta.

Mudiartha Utama, 2012,Manajemen Sumber Daya Manusia. Edisi Pertama Graha Ilmu,Yogyakarta.

Marihot Tua Efendi. (2007).Manajemen Sumber Daya Manusia : Pengadaan,Pengembangan, Pengkompensasian, dan Peningkatan Produktivitas Pegawai. Jakarta : Grasindo

Siagian, Sondang P. 2002. Kiat Meningkatkan Produktivitas Kerja. Jakarta: Adi Mahasatya.

Simamora, Henry. (2012). Manajemen Sumber Daya Manusia Edisi III. Jakarta : STIE YKPN.

Umam, Khaerul. (2010). Perilaku Organisasi. Bandung: CV. Pustaka Setia.

Wirawan. (2009). Evaluasi Kinerja Sumber Daya Manusia. Jakarta : Salemba

Empat, Jakarta. 